\title{
Vertical distribution of cadmium in marginal seas of the western Pacific Ocean
}

\author{
Su-Cheng Pai ${ }^{1}$, Hung-Yu Chen ${ }^{2}$ \\ Institute of Oceanography, National Taiwan University, P.O. Box 23-13, Taipei, Taiwan, ROC
}

(Received January 18, 1993; revision accepted February 9, 1994)

\begin{abstract}
The vertical distribution of cadmium at four locations in three marginal seas of the western Pacific Ocean are described. Data show that the surface layers at all stations were depleted $(<0.02 \mathrm{nM} \mathrm{Cd})$ and the concentration of $\mathrm{Cd}$ increased with depth up to $1.05 \mathrm{nM}$ at $1000-1200 \mathrm{~m}$. Although the shapes of the profiles for the three seas differ significantly, $\mathrm{Cd}$ concentrations show strong correlation with those of nitrate and phosphate. Average molar ratios of $(3.64 \pm 0.02) \times 10^{-4}$ and $(2.50 \pm 0.01) \times 10^{-5}(n=107)$ were found for $\mathrm{d}[\mathrm{Cd}] / \mathrm{d}\left[\mathrm{PO}_{4}\right]$ and $\mathrm{d}[\mathrm{Cd}] / \mathrm{d}\left[\mathrm{NO}_{3}\right]$, respectively. Unlike previous work reported for the eastern Pacific Ocean, intercepts were almost zero (below the detection limits) on the correlation plots for [Cd], [ $\left.\mathrm{NO}_{3}\right]$, and $\left[\mathrm{PO}_{4}\right]$ at the studied locations, and correlation coefficients $\left(\mathrm{Cd}^{\mathrm{v}} \mathrm{vs} \mathrm{NO}_{3}\right.$ and $\mathrm{PO}_{4}$ ) for all stations were 0.99 or greater. These data are consistent with the nutrient-like behavior of $\mathrm{Cd}$ as has been previously observed and significantly expand the Pacific data base for this trace element.
\end{abstract}

\section{Introduction}

It is generally known that the concentration of cadmium in the open ocean is closely related to biological activities, and that its distribution is similar to that of nitrate and phosphate. For these reasons $\mathrm{Cd}$ has been customarily classified as a nutrient-type element (Bruland, 1983). If the uptake and regeneration cycle of $\mathrm{Cd}$ in the ocean is so closely related to that of nutrients, as has been shown by many workers, then there may exist a unique ratio of $\mathrm{d}[\mathrm{Cd}] / \mathrm{d}\left[\mathrm{PO}_{4}\right]$ (like $\mathrm{dN} / \mathrm{dP}$ ratio) for global oceans, at least for the Pacific area.

\footnotetext{
${ }^{1}$ Tel.: 886-2-362-7358. Fax: 886-2-363-2912.

${ }^{2}$ Present address: Department of Earth Sciences, The University of Liverpool, Liverpool, L69 3BX, UK.
}

Unfortunately, limited data have precluded such a determination.

The current $\mathrm{Cd}$ data reported for the Pacific Basin cover the northeast Pacific (Bruland et al., 1978; Bruland, 1980; Jones and Murray, 1984), the Bering Sea and the northern Pacific Ocean (Boyle et al., 1976), the western Pacific near Guam (Kanamori, 1985), as well as the Tasman Sea of the Southern Hemisphere (Hunter and Ho, 1991). All authors have agreed that the relationship between $\mathrm{Cd}$ and nutrients are linear (except for those at extreme latitudes and up-welling areas), but the molar ratios reported $\left(\mathrm{d}[\mathrm{Cd}] / \mathrm{d}\left[\mathrm{NO}_{3}\right]\right.$ or $\left.\mathrm{d}[\mathrm{Cd}] / \mathrm{d}\left[\mathrm{PO}_{4}\right]\right)$ for the open ocean stations vary significantly, and the overlapped profiles plotted from those data show a high degree of scatter. 
Table 1

Detailed information of the sampling sites

\begin{tabular}{|c|c|c|c|c|c|c|}
\hline \multirow[t]{2}{*}{ Cruise } & \multirow{2}{*}{$\begin{array}{l}\text { Station } \\
\text { No. }\end{array}$} & \multirow{2}{*}{$\begin{array}{l}\text { Sampling date } \\
(\mathrm{m} / \mathrm{d} / \mathrm{y})\end{array}$} & \multicolumn{2}{|l|}{ Location } & \multirow{2}{*}{$\begin{array}{l}\text { Bottom depth } \\
\text { (m) }\end{array}$} & \multirow[t]{2}{*}{ Bottle type } \\
\hline & & & Latitude $(\mathrm{N})$ & Longitude (E) & & \\
\hline ORI-257 & $\begin{array}{l}17 \\
23\end{array}$ & $\begin{array}{l}10 / 13 / 1990 \\
10 / 15 / 1990\end{array}$ & $\begin{array}{l}21^{\circ} 45.1^{\prime} \\
21^{\circ} 45.0^{\prime}\end{array}$ & $\begin{array}{l}124^{\circ} 00.1^{\prime} \\
127^{\circ} 00.0^{\prime}\end{array}$ & $\begin{array}{l}5500 \\
5740\end{array}$ & $\begin{array}{l}\text { Niskin } \\
\text { Niskin }\end{array}$ \\
\hline ORI-280 & 4531 & $05 / 04 / 1991$ & $24^{\circ} 50.0^{\prime}$ & $123^{\circ} 10.0^{\prime}$ & 1700 & GoFlo \\
\hline ORI-287 & $\begin{array}{r}17 \\
157\end{array}$ & $\begin{array}{l}06 / 28 / 1991 \\
07 / 08 / 1991\end{array}$ & $\begin{array}{l}21^{\circ} 45.0^{\prime} \\
16^{\circ} 35.0^{\prime}\end{array}$ & $\begin{array}{l}124^{\circ} 00.1^{\prime} \\
119^{\circ} 00.0^{\prime}\end{array}$ & $\begin{array}{l}5500 \\
3500\end{array}$ & $\begin{array}{l}\text { GoFlo } \\
\text { GoFlo }\end{array}$ \\
\hline
\end{tabular}

There are four possible explanations for such variation:

(1) poor precision and accuracy of detecting $\mathrm{Cd}$ at such low concentrations (generally less $<1.1 \mathrm{nM}$ ), due to the limitation of the method used;

(2) different sampling, storage, pre-treatment, and analytical methods, which lead to imprecise definition of the Cd species measured;

(3) poor nutrient data accompanying the $\mathrm{Cd}$ measurements;

(4) natural variation between water masses.

Unless an analyst can ascertain the quality of the data (including nutrient data), there are risks of misinterpretation regarding bias as fact. To examine this potential problem, the acquisition of more reliable data in other unexplored areas was deemed necessary.

The present paper describes our effort of collecting cadmium data, using an extremely careful analytical scheme, in the three marginal seas around Taiwan: the western Philippine Sea, the South China Sea, and the East China Sea. The results for $\mathrm{Cd}$ and the related molar ratios with nutrients are presented as a contribution to the Pacific data base.

\section{Sampling and methods}

\subsection{Cruises and locations}

Samples were collected during three cruises aboard R/V Ocean Researcher I (ORI-257, 280, and 287) during 1990-1991. The location of stations, as well as other hydrographic infor- mation, are listed in Table 1 (also see Fig 1). Station 17 was visited twice in two separate cruises (ORI-257 and 287). Those cruises were conducted in cooperation with the WOCE (World Ocean Circulation Experiment, 1990-1996) or KEEP (Kuroshio Edge Exchange Processes, 1990-1994) programs. Hydrographic, oxygen, and nutrient data were obtained on-board by the protocols matching WOCE requirements (WOCE, 1988).

\subsection{Sampling}

Niskin bottles (Type \#1010, General Oceanic Inc., Miami, FL, USA) were used only on the first cruise (ORI-257); whereas Teflon-treated GoFlo bottles (Type \#1080, also from General Oceanic Inc.) were used for the other two cruises. The GoFlo bottles, coated with a thin layer of Teflon spray as suggested by Bruland et al. (1979), were cleaned first with a neutral detergent, then soaked in mild acid $(0.1 \mathrm{~N} \mathrm{HCl})$ for several days. The bottles were flushed thoroughly with distilled water, double distilled water, and wrapped with a layer of polyethylene film. After installation on a rosette sampler (supporting a SBE-9/11 CTD unit, SeaBird Electronics Inc., Bellevue, WA, USA), they were flushed during casts before samples were taken.

\subsection{Analytical procedure}

An on-board Chelex-100 pre-concentration technique was applied throughout this study. The details of the procedure have been described in an earlier paper (Pai et al., 1990). Two modifications of this method were made: (1) the disposable Bio- 


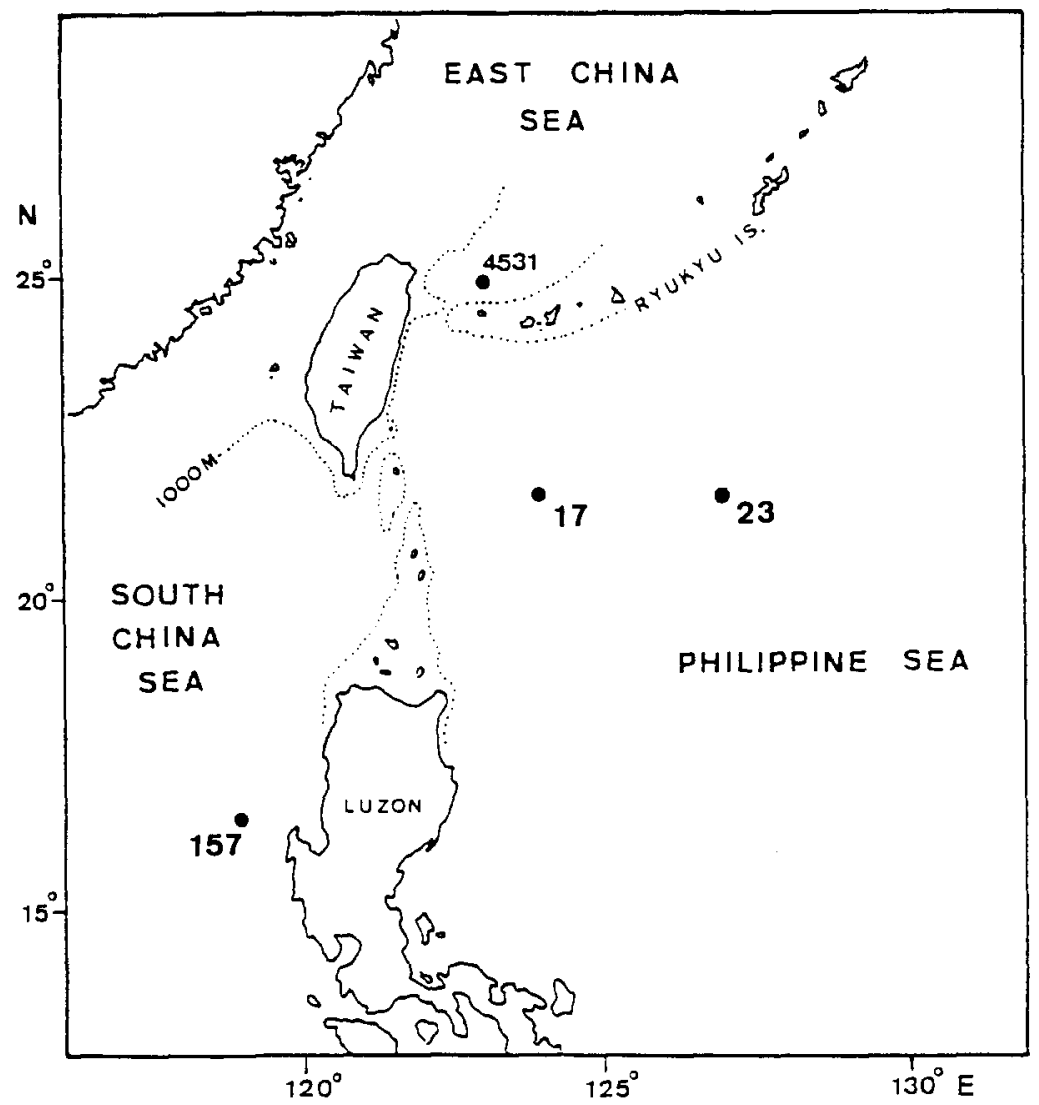

Fig. 1. Location of the sampling stations. Dashed line represents the $1000 \mathrm{~m}$ isobar.

Rad chromatographic columns (ca. $8 \mathrm{~mm}$ ID, Cat. No. \#731-1550) were used instead of the previous self-made Tygon columns; (2) each column set consisted of two columns that were connected in series (see Fig. 2). The sample was allowed to pass through both columns, but elution was carried out separately. The eluate from the upper column represented the sample, whereas the eluate from the lower column was used to examine the blank. The lower column eluate was also used as the blank matrix for constructing calibration curves using standard addition technique.

All samples were unfiltered. Upon retrieving the sampler, seawater was passed directly into 1.281 PET (polyethyleneteraphthalate) bottles each containing a $30 \mathrm{ml}$ aliquot of ammonium maleate buffer at $\mathrm{pH}$ 6.5. The sample bottle was connected to a previously packed pair of columns (each contain- ing $2.0 \mathrm{~g} \mathrm{100-200} \mathrm{mesh} \mathrm{Chelex-100} \mathrm{resins} \mathrm{in} \mathrm{ammo-}$ nium form), and hung upside-down to allow the sample to flow through at a rate of no more than $4 \mathrm{ml} \mathrm{min}{ }^{-1}$. The column pair was brought back to the laboratory for elution with $2 N$ nitric acid. Measurement of $\mathrm{Cd}$ recovered in the final eluate $(10 \mathrm{ml})$ was carried out with a Hitachi Z-8100 Zeeman effect graphite furnace atomic absorption spectrometer (GFAAS). Calibration curves were made by spiking standards into the "blank" eluates (from the second column) containing the same matrix as that of the "sample" eluates (from the first column). Reagent blank was obtained in a separate experiment by passing a double-distilled water, to which ammonium maleate buffer was added, through a column and collecting the eluate in the same way as for the samples. 

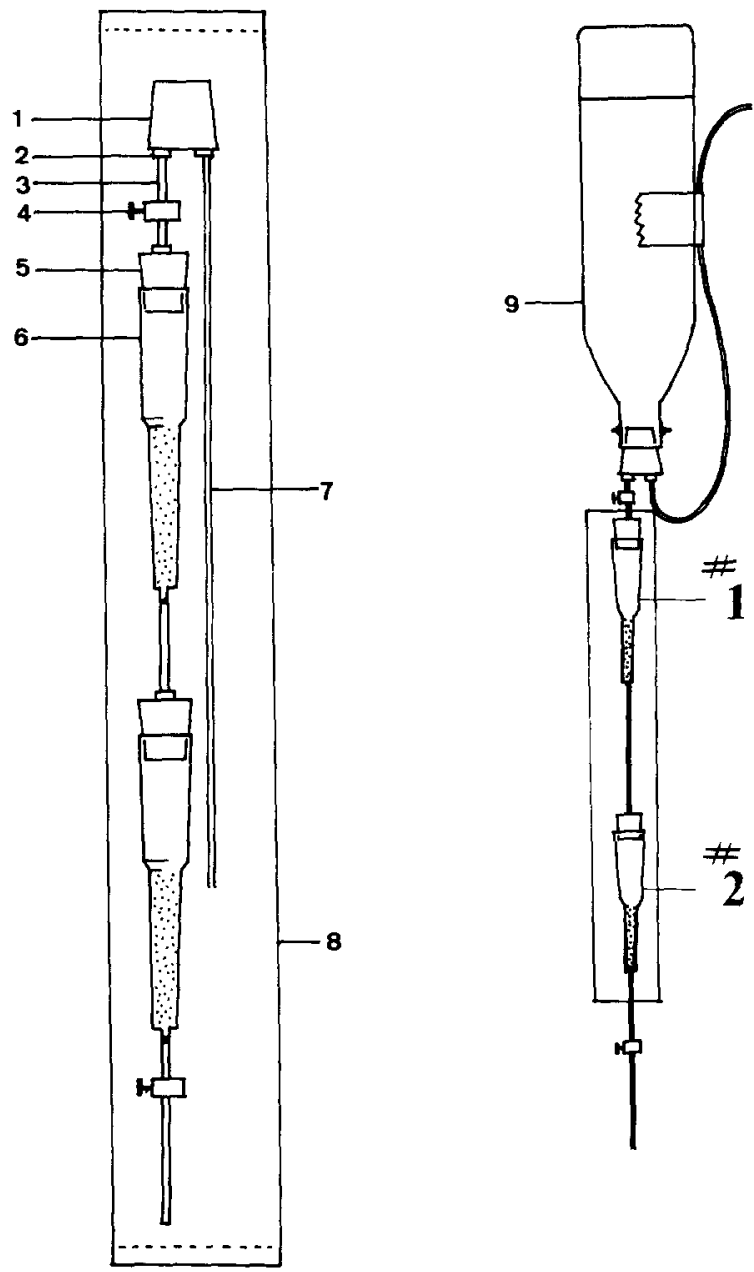

Fig. 2. (a) The pre-packed double-column set consists of two columns each packed with $2 \mathrm{~g}$ Chelex-100 resin (100-200 mesh, ammonium form). (b) Hang-bottle technique in operation. Eluate from the first column was analyzed as sample, whereas the eluate from the second column was used for checking the blanks and also for constructing calibration curve. $1=5(1 / 2)$ silicon rubber stopper; $2=$ nipple; $3=$ silicon rubber tubing $0.4 \mathrm{~mm} \mathrm{ID;} 4=$ tubing clamp; $5=4$ silicon rubber stopper; $6=$ BioRad PP column; $7=$ ventilation tube; $8=\mathrm{PE}$ bag; $9=1280 \mathrm{ml}$ PET bottle.

\section{Results and discussion}

\subsection{Calibration, blank, and recovery}

The laboratory test of the precision and accuracy for $\mathrm{Cd}$ determination using the Chelex-100 preconcentration-GFAAS method has been performed prior to field sampling. This involved the following: a filtered surface seawater sample was purified by ion-exchange through a large Chelex100 column (containing $10 \mathrm{~g}$ resin) at a low flow rate $\left(1 \mathrm{ml} \mathrm{min}{ }^{-1}\right)$. Recovery test was as follows: aliquots of 11 of the purified seawater were spiked with $0,0.445,0.890,1.335 \mathrm{nmol} \mathrm{Cd}$, respectively, after adding $25 \mathrm{ml}$ of ammonium maleate buffer each mixture was allowed to pass through the column pair. Known amounts of $\mathrm{Cd}$ were spiked to the blank matrix for the construction of the calibration curve (Table 2). The results of GFAAS measurements for the eluates (10 $\mathrm{ml}$ aliquots) from both columns are shown in Table 3. It was found that all spikes were recovered quantitatively (98-105\%) from the first column. The small but consistent GFAAS signal produced by the second column eluate was equivalent to an original $\mathrm{Cd}$ concentration of ca. $0.02 \mathrm{nM}$, almost the same as that produced by the reagent blank. The average blank value found for over 200 sets of field samples was $0.02 \pm 0.004 \mathrm{nmol}$ (in $1250 \mathrm{ml}$ seawater), indicating a detection limit of ca. $0.02 \mathrm{nM} \mathrm{Cd}$ (taking 4.65 fold of the deviation of the blank). It should be noted that the blank prepared in this way did not include the bottle and buffer blanks. However, an extended experiment showed that all blanks were no more than the detection limit, so the difference was not significant. An analysis of the precision of the proposed method was also carried out on-board ship on a deep seawater sample spiked with $1 \mathrm{nM} \mathrm{Cd}$. An overall analytical error (including sampling error) of ca. $4 \%$ at $1 \mathrm{nM}$ level was achieved, and the recovery of the spike was $99.5 \pm 2 \%(n=4)$.

\subsection{Quality check}

To minimize the inclusion of spurious data caused by leakage of the GoFlo bottles, a careful QA/QC scheme was used. Each data set (including CTD data) was first cross-checked by the correlation plots of various physical and chemical parameters, including temperature, salinities (both by CTD and manual methods), concentrations of nitrate and phosphate, as well as the record of bottle numbers. The $T-S, \mathrm{~N}-\mathrm{P}$, and $T$ nutrient plots gave primary check of quality of nutrient measurements (see Fig. 4). Any off-set 
Table 2

Typical calibration performed by spiking known amounts of $\mathrm{Cd}$ to $10 \mathrm{ml}$ of blank eluate

\begin{tabular}{llrrrrrr}
\hline $\begin{array}{l}\text { Spiked amount } \begin{array}{l}\text { Final vol } \\
(\mathrm{nmol})\end{array} \\
\text { (mL) }\end{array}$ & $\begin{array}{l}\text { Raw absorbance } \\
\times 1000\end{array}$ & Mean & $\begin{array}{l}\text { RSD } \\
(\%)\end{array}$ \\
\cline { 2 - 6 } & & $\mathrm{i}$ & ii & iii & & \\
\hline 0 & 10.0 & 2 & 3 & 3 & 3 & 17.7 \\
0.445 & 10.1 & 63 & 65 & 64 & 64 & 1.3 \\
0.890 & 10.2 & 128 & 126 & 124 & 126 & 1.3 \\
1.335 & 10.3 & 185 & 189 & 188 & 187 & 0.9 \\
\hline
\end{tabular}

Spiking was made by added $0,0.1,0.2,0.3 \mathrm{ml}$ of $0.5 \mathrm{ppm} \mathrm{Cd}$ standard solution to $10 \mathrm{ml}$ of the eluate from a Chelex-100 column ( 1 l purified seawater passed through).

point on the $T$-nutrient diagram, if not due to the analytical error, could indicate a possible leakage due to the faulty closure of the bottle. If the leakage was obvious, further analysis of $\mathrm{Cd}$ was abandoned. The discard rate for the three cruises was $8 \%$ and was attributed to leaking Go-Flo bottles.

\subsection{Hydrographic and nutrient data}

The profiles of temperature, salinity, oxygen, and nutrients for the three marginal seas are shown in Fig. 3. The cross-plots of $T-S$ and $T-$ nutrients at all stations are shown in Fig. 4. It can be seen that the three seas show strong difference in hydrography, although they are connected with each other through channels. The western Philippine Sea covers the largest area. Profiles of temperature, salinity, oxygen, and nutrients at the three stations from this region are all similar to each other, and also to those of the nearby stations on other WOCE cruises and the INDOPAC cruise Leg 3. Salinity maxima $(>34.9)$ and minima $(<34.2)$ are found within the $100-200$ and $600-$ $700 \mathrm{~m}$ layers, respectively. The concentrations of dissolved oxygen in the upper layer (from surface to $200 \mathrm{~m}$ ) are saturated or slightly over-saturated; whereas nutrients are not detectable above the thermocline. Obvious concentration maxima have been found at $1000-1100 \mathrm{~m}$ for both nitrate and phosphate. Below the maxima, the nutrient concentrations decrease slightly with depth. Signifi-
Table 3

Recovery test on a purified seawater spiked with known amounts of cadmium using the double-column technique

\begin{tabular}{lll}
\hline $\begin{array}{l}\text { Spiked amount } \\
\text { (nmol) }\end{array}$ & $\begin{array}{l}\text { Raw absorbance } \times 1000 \\
\text { for } 10 \text { ml eluate from }\end{array}$ & $\begin{array}{l}\text { Recovery } \\
(\%)\end{array}$ \\
\cline { 2 - 3 } & 1st column $\quad$ 2nd column & \\
\hline
\end{tabular}

$\begin{array}{lll}\text { Distilled water (1 l) } & & \\ 0 & 2 & 2 \\ 0 & 4 & 2 \\ 0 & 2 & 3\end{array}$

Purified seawater (1 l)

$\begin{array}{lrrr}0 & 3 & 3 & - \\ 0 & 3 & 2 & - \\ 0 & 4 & 3 & - \\ 0.445 & 65 & 2 & 102 \\ 0.445 & 66 & 4 & 100 \\ 0.445 & 68 & 3 & 105 \\ 0.890 & 126 & 2 & 99 \\ 0.890 & 128 & 3 & 100 \\ 0.890 & 131 & 2 & 103 \\ 1.335 & 198 & 2 & 103 \\ 1.335 & 190 & 2 & 99 \\ 1.335 & 197 & 3 & 102\end{array}$

Ammonium maleate buffer $(25 \mathrm{ml})$ was added to each sample. Each of the data represents the mean value of triplicate measurements on GFAAS. Recovery was calculated for the lst column only, using the calibration curve made in Table 2 .

cant seasonal variation on any parameter through the water column has not been found, indicating that the water mass is fairly stable in those parameters over time.

The East China Sea Basin is divided from the Philippine Basin by the Ryukyu Arc, and the channels between the island chain are quite shallow (up to few hundred meters) except for a deep narrow underwater gap (few $\mathrm{km}$ wide, $1000 \mathrm{~m}$ deep) between the Yunagoni (Japan) and Taiwan islands, where the Kuroshio's axis passes through. The strong current carries the surface and sub-surface Philippine Sea water into the East China Sea. The surface water is mixed with shelf water, but the sub-surface layer $(100-700 \mathrm{~m})$ retains the same properties as those of the Philippine Sea. No nutrient maxima in the deeper layers $(>800 \mathrm{~m}$ ) have been observed.

The South China Sea below $1000 \mathrm{~m}$ is also like an isolated basin, with only two narrow channels allowing the exchange with the Philippine Sea. 

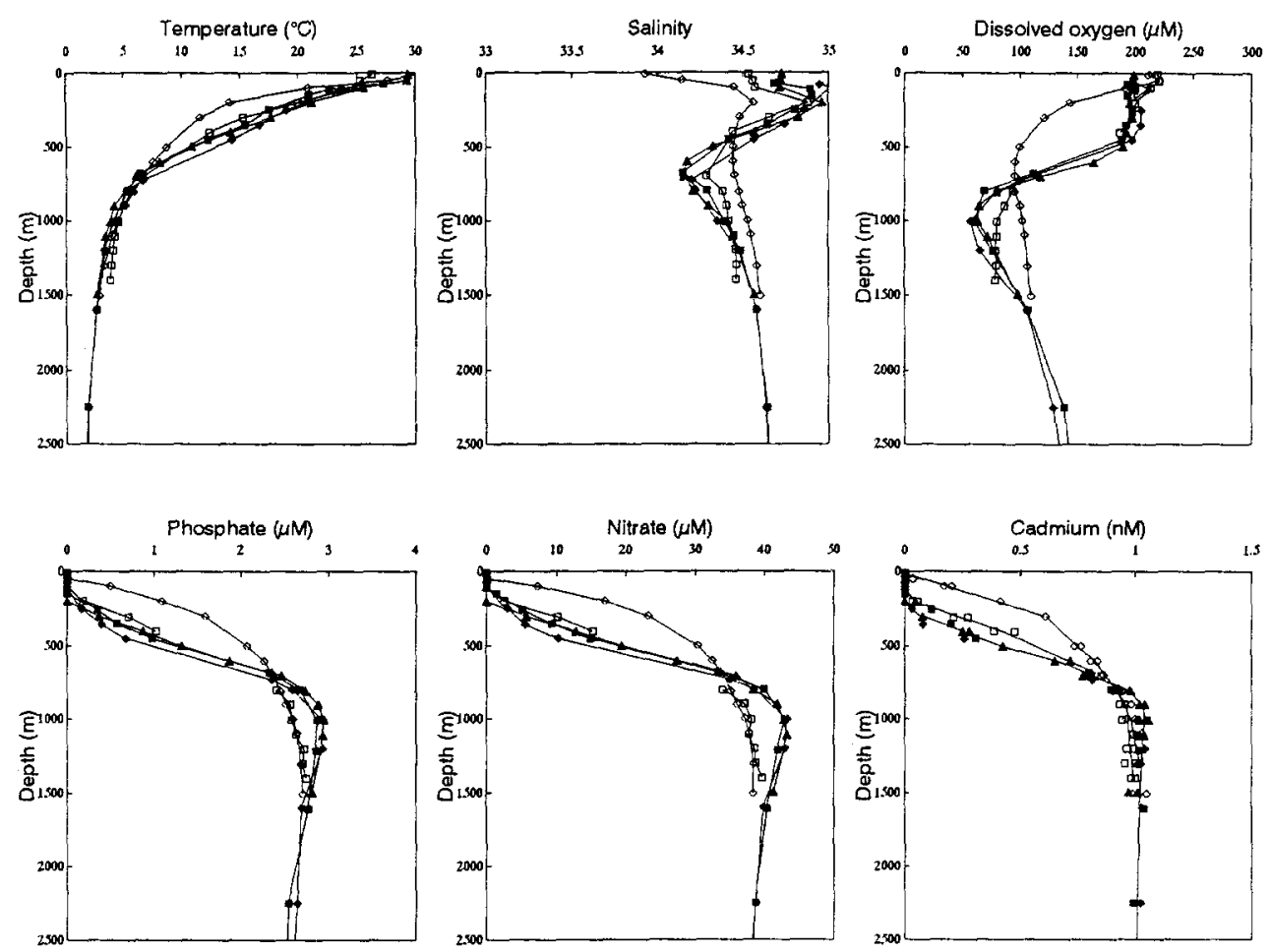

Fig. 3. Hydrographic, nutrient, and cadmium profiles for the five stations. Western Philippine Sea: $\square=$ ORI-257 Station 17 ; $\bullet=$ ORI257 Station 23; $\boldsymbol{\Delta}=$ ORI-287 Station 17. East China Sea: $\square=$ ORI-280 Station 4531. South China Sea: $\diamond=$ ORI-287 Station 157.

Both channels are in the $\mathrm{N}-\mathrm{S}$ direction at the northeast part of the Luzon Channel. Although there is some indication that the Philippine Sea water intrudes frequently into the South China Sea, this circulation is limited only to surface layers (up to $300 \mathrm{~m}$ ) of the northern area (Shaw, 1989). It is likely that the water column off west Luzon did not receive direct influence from the Kuroshio at the time of this study. The surface mixing layer was comparatively shallow (ca. $75 \mathrm{~m}$ ), below which the concentration of oxygen decreased rapidly with a sharp increase in nutrient concentrations. Compared to the Philippine Sea, the middle layer $(300-1000 \mathrm{~m})$ of the South China Sea was high in nutrients and low in oxygen and temperature. No above-bottom nutrient maxima have been be found at Station 157 , nor at other nearby locations (Gong et al., 1992).

The relationship between concentrations of nitrate and phosphate is linear at all stations (Fig.
4), indicating similar cycling of nitrate and phosphate in the three seas.

\subsection{Cd profiles}

The results of the measurement for cadmium at the 5 stations including hydrographic data, are given in Table 4. Profiles of up to $2500 \mathrm{~m}$ are shown in Fig. 3. Some of the samples were replicated (collected from two bottles). Data of Cd each represents the mean value of GFAAS measurements performed in triplicate.

The profiles of Cd in the West Philippine Sea at Stations 257-17, 257-23, and 287-17 show good agreement. It can be seen that in the surface layers $\mathrm{Cd}$ is completely depleted, and the concentration increases with depth to a maximum of around 1.05 $\mathrm{nM} \mathrm{Cd}$ at $1000-1200 \mathrm{~m}$, then maintains at a steady but slightly decreasing trend $(0.95-1.00 \mathrm{nM})$ in deeper waters. No significant differences have been found at Station 17 for the two cruises (even 

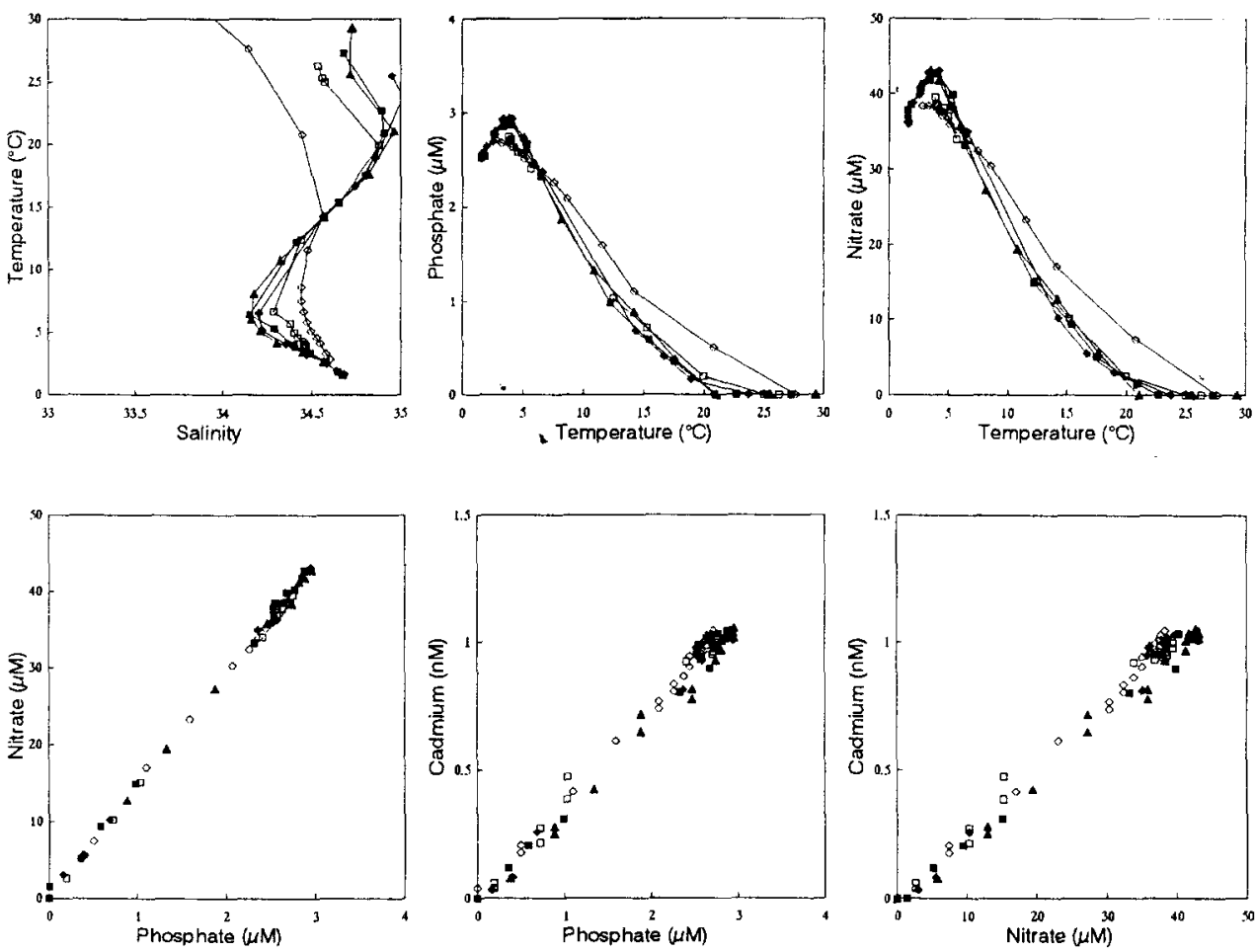

Fig. 4. Correlation plots of $T-S, T-$ nutrient, $N-P$, and $\mathrm{Cd}$-nutrient obtained at all stations in this study. For legend see Fig. 3.

using different types of bottles), nor for Station 23 which is located $270 \mathrm{~km}$ away.

The Cd distribution in the South China Sea also shows surface water depletion followed by an increase in concentration with depth to ca. 1.0 $\mathrm{nM}$ at $1000 \mathrm{~m}$. However, the South China Sea profile looks very different from that obtained in the Philippine Sea. The major difference is the strength of $\mathrm{Cd}$ gradient within the thermocline. It can be clearly seen that $\mathrm{Cd}$ concentrations increased sharply at a depth of ca. $100 \mathrm{~m}$ at station 287-157, and reached $0.6 \mathrm{nM}$ at $300 \mathrm{~m}$ (Fig. 3). However, in the Philippine Sea, the sharp increase in Cd started deeper, i.e. at $300-400 \mathrm{~m}$, and reached $0.6 \mathrm{nM}$ at around $600 \mathrm{~m}$.

Station 4531 (ORI-280) in the East China Sea has a shallower bottom depth $(1700 \mathrm{~m})$. In the upper layer $(0-700 \mathrm{~m})$ the $\mathrm{Cd}$ distribution pattern was very similar to that found in the Philippine Sea, but the lower part of the profile $(700-1500 \mathrm{~m})$ followed the trend of the South China Sea. The highest concentration (ca. $1.0 \mathrm{nM} \mathrm{Cd}$ ) occurred at 1000-1500 m, without a prominent maximum.

\section{$3.5 N / P, C d / N$ and $C d / P$ ratios}

The least-square regression coefficients for the concentrations of nutrients and $\mathrm{Cd}$ in the three seas are shown in Table 5. In the studied areas, phosphate, nitrate, and cadmium were all depleted in the surface layer; and on the correlation plots all intercepts were below the detection limits and not significantly different from zero. The equations after zero-intercept linear regression for the three parameters are:

$$
\begin{aligned}
{\left[\mathrm{NO}_{3}\right]=} & (14.53 \pm 0.04) \times\left[\mathrm{PO}_{4}\right](r=0.999, n=69) \\
{[\mathrm{Cd}]=} & (0.0250 \pm 0.0001) \\
& \times\left[\mathrm{NO}_{3}\right](r=0.990, n=107) \\
{[\mathrm{Cd}]=} & (0.364 \pm 0.002) \\
& \times\left[\mathrm{PO}_{4}\right](r=0.992, n=107)
\end{aligned}
$$

where [Cd] and nutrients are in $\mathrm{nM}$ and $\mu \mathrm{M}$ units, respectively.

Although correlation coefficients are high, any 
Table 4

Hydrographic data and results of Cd analysis at Stations in the western Philippine Sea, the South China Sea, and the East China Sea (Cruises ORI-257, 280, and 287)

\begin{tabular}{|c|c|c|c|c|c|c|}
\hline $\begin{array}{l}\text { Pressure } \\
\text { (db) }\end{array}$ & $\begin{array}{l}\text { Temperature } \\
\left({ }^{\circ} \mathrm{C}\right)\end{array}$ & Salinity & $\begin{array}{l}\text { Oxygen } \\
(\mu \mathrm{M})\end{array}$ & $\begin{array}{l}{\left[\mathrm{PO}_{4}\right]} \\
(\mu \mathrm{M})\end{array}$ & $\begin{array}{l}{\left[\mathrm{NO}_{3}\right]} \\
(\mu \mathrm{M})\end{array}$ & $\begin{array}{l}{[\mathrm{Cd}]} \\
(\mathrm{nM})\end{array}$ \\
\hline \multicolumn{7}{|c|}{ ORI-257 Station 17} \\
\hline 75 & 27.30 & 34.683 & 192 & nd & nd & nd \\
\hline 111 & 22.67 & 34.895 & 200 & nd & nd & nd \\
\hline 151 & 20.91 & 34.906 & 194 & nd & 1.4 & nd \\
\hline 254 & 17.51 & 34.802 & 197 & 0.35 & 5.1 & 0.12 \\
\hline 352 & 15.40 & 34.647 & 192 & 0.58 & 9.4 & 0.20 \\
\hline 452 & 12.21 & 34.411 & 187 & 0.98 & 14.9 & 0.31 \\
\hline 680 & 6.41 & 34.151 & 112 & 2.32 & 33.3 & 0.80 \\
\hline 797 & 5.34 & 34.290 & 69 & 2.67 & 39.9 & 0.90 \\
\hline 1002 & 4.03 & 34.395 & 61 & 2.87 & 42.9 & 1.05 \\
\hline 1207 & 3.35 & 34.486 & 77 & 2.85 & 41.8 & 1.01 \\
\hline 1602 & 2.61 & 34.579 & 107 & 2.77 & 40.4 & 1.03 \\
\hline 2251 & 1.84 & 34.643 & 139 & 2.54 & 38.6 & 0.99 \\
\hline 3301 & 1.56 & 34.671 & 154 & 2.52 & 37.8 & 0.95 \\
\hline 4294 & 1.58 & 34.678 & 156 & 2.53 & 36.9 & 0.95 \\
\hline \multicolumn{7}{|c|}{ ORI-257 Station 23} \\
\hline 76 & 25.47 & 34.949 & 199 & nd & nd & nd \\
\hline 108 & 23.70 & 35.012 & 197 & nd & nd & nd \\
\hline 252 & 18.94 & 34.858 & 205 & 0.16 & 2.9 & 0.03 \\
\hline 354 & 16.68 & 34.744 & 205 & 0.40 & 5.5 & 0.08 \\
\hline 453 & 14.30 & 34.565 & 197 & 0.68 & 10.2 & 0.26 \\
\hline 731 & 6.58 & 34.201 & 99 & 2.36 & 35.0 & 0.81 \\
\hline 798 & 5.17 & 34.219 & 80 & 2.59 & 38.5 & 0.93 \\
\hline 1003 & 4.11 & 34.353 & 58 & 2.94 & 43.1 & 1.01 \\
\hline 1199 & 3.26 & 34.470 & 65 & 2.93 & 42.8 & 1.04 \\
\hline 1600 & 2.53 & 34.582 & 106 & 2.69 & 39.8 & 1.03 \\
\hline 2251 & 1.94 & 34.637 & 129 & 2.64 & 38.7 & 1.02 \\
\hline 3298 & 1.60 & 34.669 & 150 & 2.57 & 36.3 & 0.99 \\
\hline 4201 & 1.58 & 34.678 & 155 & 2.52 & 36.1 & 0.98 \\
\hline 5000 & 1.65 & 34.680 & 154 & 2.52 & 35.9 & 0.95 \\
\hline \multicolumn{7}{|c|}{ ORI-287 Station 17} \\
\hline 11 & 29.36 & 34.727 & 198 & nd & nd & nd, nd \\
\hline 53 & 29.28 & 34.722 & 198 & nd & nd & nd, nd \\
\hline 103 & 25.60 & 34.716 & 212 & nd & nd & nd, nd \\
\hline 202 & 21.07 & 34.963 & 195 & nd & nd & nd, 0.05 \\
\hline 301 & 17.64 & 34.822 & 197 & 0.37 & 5.6 & $0.08,0.08$ \\
\hline 401 & 14.18 & 34.569 & 193 & 0.88 & 12.8 & $0.25,0.28$ \\
\hline 499 & 10.82 & 34.322 & 189 & 1.33 & 19.4 & $0.43,0.43$ \\
\hline 600 & 8.12 & 34.174 & 164 & 1.87 & 27.3 & $0.65,0.72$ \\
\hline 701 & 6.02 & 34.156 & 117 & 2.46 & 35.9 & $0.81,0.78$ \\
\hline 801 & 5.12 & 34.208 & 80 & 2.74 & 38.4 & $0.98,0.93$ \\
\hline 899 & 4.14 & 34.298 & 65 & 2.88 & 41.8 & $1.02,1.04$ \\
\hline 1003 & 3.86 & 34.408 & 64 & 2.95 & 42.8 & $1.06,1.02$ \\
\hline 1106 & 3.41 & 34.444 & 72 & 2.94 & 43.2 & $1.02,1.04$ \\
\hline 1495 & 2.63 & 34.562 & 98 & 2.81 & 41.4 & $1.01,0.97$ \\
\hline \multicolumn{7}{|c|}{ ORI-280 Station 4531} \\
\hline 13 & 26.30 & 34.535 & 219 & nd & nd & nd, nd \\
\hline 55 & 25.32 & 34.561 & 221 & nd & nd & nd, nd \\
\hline
\end{tabular}


Table 4 (continued)

\begin{tabular}{|c|c|c|c|c|c|c|}
\hline $\begin{array}{l}\text { Pressure } \\
\text { (db) }\end{array}$ & $\begin{array}{l}\text { Temperature } \\
\left({ }^{\circ} \mathrm{C}\right)\end{array}$ & Salinity & $\begin{array}{l}\text { Oxygen } \\
(\mu \mathrm{M})\end{array}$ & $\begin{array}{l}{\left[\mathrm{PO}_{4}\right]} \\
(\mu \mathrm{M})\end{array}$ & $\begin{array}{l}{\left[\mathrm{NO}_{3}\right]} \\
(\mu \mathrm{M})\end{array}$ & $\begin{array}{l}{[\mathrm{Cd}]} \\
(\mathrm{nM})\end{array}$ \\
\hline 101 & 25.00 & 34.574 & 214 & nd & nd & nd, nd \\
\hline 202 & 19.95 & 34.882 & 200 & 0.19 & 2.6 & $0.04,0.06$ \\
\hline 304 & 15.29 & 34.655 & 197 & 0.71 & 10.2 & $0.21,0.27$ \\
\hline 402 & 12.45 & 34.443 & 187 & 1.03 & 15.2 & $0.39,0.48$ \\
\hline 701 & 6.67 & 34.286 & - & - & - & $0.85,0.81$ \\
\hline 801 & 5.68 & 34.380 & 94 & 2.41 & 34.0 & 0.92 \\
\hline 900 & 4.97 & 34.404 & 87 & 2.57 & 37.0 & $0.95,0.93$ \\
\hline 1002 & 4.57 & 34.421 & 81 & 2.58 & 38.1 & 0.94 \\
\hline 1101 & 4.27 & 34.448 & 80 & 2.63 & 37.7 & $1.01,0.99$ \\
\hline 1200 & 4.06 & 34.454 & 79 & 2.72 & 38.5 & $0.99,0.96$ \\
\hline 1299 & 3.92 & 34.464 & 80 & 2.70 & 38.7 & $0.95,1.00$ \\
\hline 1400 & 3.85 & 34.462 & 79 & 2.75 & 39.6 & $0.98,1.00$ \\
\hline \multicolumn{7}{|c|}{ ORI-287 Station 157} \\
\hline 10 & 30.32 & 33.926 & 212 & nd & nd & nd, nd \\
\hline 50 & 27.66 & 34.142 & 220 & nd & nd & nd, 0.04 \\
\hline 101 & 20.80 & 34.446 & 191 & 0.50 & 7.3 & $0.20,0.17$ \\
\hline 202 & 14.17 & 34.564 & 143 & 1.10 & 17.0 & $0.42,0.42$ \\
\hline 299 & 11.57 & 34.480 & 121 & 1.59 & 23.2 & $0.61,0.61$ \\
\hline 500 & 8.65 & 34.441 & 99 & 2.08 & 30.3 & $0.74,0.77$ \\
\hline 600 & 7.52 & 34.441 & 96 & 2.26 & 32.4 & $0.83,0.81$ \\
\hline 698 & 6.66 & 34.454 & 95 & 2.37 & 33.9 & $0.86,0.86$ \\
\hline 808 & 5.83 & 34.476 & 95 & 2.45 & 35.2 & $0.90,0.94$ \\
\hline 897 & 5.14 & 34.497 & 100 & 2.51 & 36.0 & 0.98 \\
\hline 996 & 4.50 & 34.530 & 103 & 2.60 & 37.1 & $1.00,0.96$ \\
\hline 1094 & 4.06 & 34.547 & 105 & 2.64 & 37.8 & $1.03,0.99$ \\
\hline 1303 & 3.29 & 34.580 & 107 & 2.68 & 38.3 & $1.01,1.02$ \\
\hline 1507 & 2.82 & 34.603 & 109 & 2.71 & 38.4 & $0.99,1.05$ \\
\hline
\end{tabular}

$n d=$ below detection limits; $0.07 \mu \mathrm{M}$ for phosphate, $0.5 \mu \mathrm{M}$ for nitrate, and $0.02 \mathrm{nM}$ for cadmium.

Duplicate measurements: samples were collected by two GoFlo bottles.

systematic error of the measurements of either the nutrients or cadmium could cause significant bias. A further check was needed to ascertain the accuracy of the slope values. The accuracy of nutrient measurements were evaluated by comparing the data from the $2000-2500 \mathrm{~m}$ layer obtained for the whole Cruise ORI-257 (WOCE PR-20 Expedition) with that of selected stations (Stations 39-45) obtained from the INDOPAC Leg-3 cruise (1976). The differences of nitrate and phosphate data between the two sets of data were all within $2 \%$. The $d N / d P$ ratios were 14.57 for the ORI-257 and 14.62 for the INDOPAC, respectively. The accuracy of the $\mathrm{Cd}$ analysis was checked in the laboratory with NASS-3 Standard Seawater. The recovery indicated a relative accuracy of $\pm 3 \%$. Thus the possible relative error $( \pm 1 \sigma)$ of the two molar ratios $(\mathrm{dCd} / \mathrm{dN}$ and $\mathrm{dCd} / \mathrm{dP})$ should not exceed $\pm 5 \%$.

\subsection{Comparison with east Pacific data}

Among all literature data available for the Pacific Ocean, the work by Bruland (1980) has provided probably the best data quality, judging from the smoothness of the profiles and the high correlation coefficients on molar ratios of 
Table 5

Regression data for cadmium and nutrients in this study

\begin{tabular}{|c|c|c|c|c|}
\hline Cruise/station & Slope & Intercept & $n$ & $r$ \\
\hline \multicolumn{5}{|l|}{$\left[\mathrm{NO}_{3}\right]$ vs. $\left[\mathrm{PO}_{4}\right]$} \\
\hline ORI-257 Station 17 & $14.62 \pm 0.15$ & 0.45 & 14 & 0.9987 \\
\hline ORI-257 Station 23 & $14.55 \pm 0.14$ & 0.11 & 14 & 0.9989 \\
\hline ORI-280 Station 4531 & $14.36 \pm 0.10$ & 0.02 & 13 & 0.9995 \\
\hline ORI-287 Station 17 & $14.50 \pm 0.10$ & 0.06 & 14 & 0.9994 \\
\hline ORI-287 Station 157 & $14.21 \pm 0.11$ & 0.34 & 14 & 0.9993 \\
\hline All stations & $14.46 \pm 0.06$ & 0.17 & 69 & 0.9987 \\
\hline All stations ${ }^{\mathrm{a}}$ & $14.53 \pm 0.04$ & & 69 & 0.9987 \\
\hline \multicolumn{5}{|l|}{$[\mathrm{Cd}]$ vs. $\left[\mathrm{NO}_{3}\right]$} \\
\hline ORI-257 Station 17 & $0.02510 \pm 0.0006$ & -0.02 & 14 & 0.9937 \\
\hline ORI-257 Station 23 & $0.02567 \pm 0.0008$ & -0.02 & 14 & 0.9876 \\
\hline ORI-280 Station 4531 & $0.02556 \pm 0.0004$ & 0.00 & 24 & 0.9955 \\
\hline ORI-287 Station 17 & $0.02424 \pm 0.0004$ & -0.01 & 28 & 0.9934 \\
\hline ORI-287 Station 157 & $0.02618 \pm 0.0004$ & -0.00 & 27 & 0.9951 \\
\hline All stations & $0.02529 \pm 0.0002$ & -0.01 & 107 & 0.9901 \\
\hline All stations ${ }^{\mathrm{a}}$ & $0.02509 \pm 0.0001$ & & 107 & 0.9900 \\
\hline \multicolumn{5}{|l|}{$[\mathrm{Cd}]$ vs. $\left[\mathrm{PO}_{4}\right]$} \\
\hline ORI-257 Station 17 & $0.367 \pm 0.009$ & -0.01 & 14 & 0.9935 \\
\hline ORI-257 Station 23 & $0.374 \pm 0.010$ & -0.02 & 14 & 0.9911 \\
\hline ORI-280 Station 4531 & $0.367 \pm 0.005$ & 0.00 & 24 & 0.9954 \\
\hline ORI-287 Station 17 & $0.352 \pm 0.005$ & -0.01 & 28 & 0.9943 \\
\hline ORI-287 Station 157 & $0.372 \pm 0.005$ & 0.01 & 27 & 0.9961 \\
\hline All stations & $0.366 \pm 0.003$ & -0.00 & 107 & 0.9920 \\
\hline All stations ${ }^{\mathrm{a}}$ & $0.364 \pm 0.002$ & & 107 & 0.9920 \\
\hline
\end{tabular}

${ }^{\text {a }}$ Force-zero linear regression process was used, because all intercepts were apparently less than the detection limits $(0.5$ and $0.07 \mu \mathrm{M}$ for nitrate and phosphate respectively; $0.02 \mathrm{nM}$ for cadmium).

Concentration units are $\mathrm{nM}$ for $\mathrm{Cd}$ and $\mu \mathrm{M}$ for nutrients.

more than 0.99. Other data, either with zigzag shaped Cd profiles or accompanied with poor temperature-nutrient relationships, were not quoted for comparison.

If the $\mathrm{d}[\mathrm{Cd}] /[$ nutrient] ratios obtained in this study are compared with that reported by Bruland for the eastern Pacific region, it is interesting to see the ratios, representing both sides of the Pacific Basin, agree well within only a few percent. The $\mathrm{d}[\mathrm{Cd}] / \mathrm{d}\left[\mathrm{PO}_{4}\right]$ ratio obtained in this study $\left(3.64 \times 10^{-4}\right)$ is ca. $4 \%$ higher than the $3.47 \times 10^{-4}$ reported by Bruland, whereas the $\mathrm{d}[\mathrm{Cd}] /\left[\mathrm{NO}_{3}\right]$ ratio $\left(2.50 \times 10^{-5}\right)$ is ca. $7 \%$ higher than the $2.35 \times 10^{-5}$ for the Cruise H-77 Station 17 in Bruland's work. The differences were insignificant compared to the relative slope bias of $\pm 5 \%$. The maximum Cd concentrations found at the $1000 \mathrm{~m}$ layer in the two studies were similar. ranging from 1.0 to $1.1 \mathrm{nM}$.

\section{Conclusion}

In the present study we have collected highquality cadmium and nutrient data at four locations (5 stations) in three marginal seas of the western Pacific Ocean (the western Philippine Sea, the South China Sea, and the East China Sea). The highest $\mathrm{Cd}$ concentration was ca. $1.05 \mathrm{nM}$ found in the 1000-1200 m layer of the Philippine Sea. Surface depletion was found at all stations for both $\mathrm{Cd}$ and nutrients. The relationships between $\mathrm{Cd}$ (in $\mathrm{nM}$ units) and nutrients (in $\mu \mathrm{M}$ units) were linear and were almost identical for the three seas, to be 
$[\mathrm{Cd}]=(0.364 \pm 0.002) \times\left[\mathrm{PO}_{4}\right]$, and $[\mathrm{Cd}]=(0.0250$ $\pm 0.0001) \times\left[\mathrm{NO}_{3}\right] \quad(n=107)$. Intercepts on the cross-plots were not significantly different from zero. It is not appropriate to compare those ratio values with that reported by other workers in other areas without considering the data quality (both $\mathrm{Cd}$ and nutrients) in term of accuracy. Nonetheless, since such linear relationships have been consistently found in many parts of the Pacific Ocean, we suggest that the molar ratios of $d[\mathrm{Cd}] / d\left[\mathrm{PO}_{4}\right]$ and $\left.\mathrm{d}[\mathrm{Cd}] / \mathrm{d}^{2} \mathrm{NO}_{3}\right]$ are invariant over the whole open Pacific Basin averaging $(3.55 \pm 0.20) \times 10^{-4}$ and $(2.42 \pm 0.15) \times 10^{-5}$, respectively. If this is true then these ratios may be used for identifying the sources or sinks, such as anthropogenic and hydrothermal inputs, of this metal in different areas.

\section{Acknowledgements}

The authors would like to thank K.T. Jiann, K.L. Jeng, C.C. Yang, T.Y. Kao, the ROC WOCE Expedition team, Captain and crew of the $\mathrm{R} / \mathrm{V}$ Ocean Researcher I, for their kind assistance at sea. Thanks are also due to C.T. Liu and G.C. Gong, for their support and criticism. The authors express their sincere gratefulness to Ethel Pai and to K.H. Coale who kindly corrected the manuscript. This project was sponsored by the National Science Council of the Republic of China under the contract NSC830209-M002a-20.

\section{References}

Boyle, E.A., Sclater, F. and Edmond, J.M., 1976. On the marine geochemistry of cadmium. Nature, $263: 42-44$.

Bruland, K.W., 1980. Oceanogrpahic distributions of cadmium, zinc, nickel, and copper in the north Pacific. Earth Planet. Sci. Lett., 47: 176-198.

Bruland, K.W., 1983. Trace elements in seawater. In: J.P. Riley and R. Chester (Editors), Chemical Oceanography, 8. Academic, London, pp. 157-221.

Bruland, K.W., Knauer, G.A. and Martin, J.H., 1978. Cadmium in northeast Pacific waters. Limnol. Oceanogr., 23: 618-625.

Bruland, K.W., Franks, R.P., Knauer, G.A. and Martin, J.H., 1979. Sampling and analytical methods for the determination of copper, cadmium, zinc and nickel at the nanogram per liter level in seawater. Anal. Chim. Acta, 105: 233-245.

Gong, G.C., Liu, K.K., Liu, C.T. and Pai, S.C., 1992. The chemical hydrography of the South China Sea west of Luzon and a comparison with the west Philippine Sea. Terr. Atmos. Ocean. Sci. Taiwan, 3(4): 587-602.

Hunter, K.A. and Ho, F.W.T., 1991. Phosphorus-cadmium cycling in the northeast Tasman Sea, 35-40 $\backslash \mathrm{kG} \mathrm{S}$. Mar. Chem., 33: 279-298.

Jones, C.J. and Murray, J.W., 1984. Nickel, cadmium and copper in the northeast Pacific off the coast of Washington. Limnol. Oceanogr., 29(4): 711-720.

Kanamori, S., 1985. Cycling of materials in the ocean. In: S. Kajiura (Editor), Ocean Characteristics and Their Changes. Koseisha Koseikaku, Tokyo, pp. 247-261 (in Japanese).

Pai, S.C., Fang, T.H., Chen, C.T.A. and Jeng, K.L., 1990. A low contamination Chelex-100 technique for shipboard pre-concentration of heavy metals in seawater. Mar. Chem., 29: 295- 306.

Shaw, P.T., 1989. The intrusion of water masses into the sea southwest Taiwan. J. Geophys. Res., 94(C12): 18,213$18,226$.

WOCE, 1988. World Ocean Circulation Experiments Implementation Plan, 1: Detailed Requirements. WOCE Int. Plann. Off., Wormley, pp. 2.1-2.8. 